\title{
PERBEDAAN MUTU PERMEN JELI Kappaphycus alvarezii YANG DIKEMAS EDIBLE FILM BERBASIS GELATIN-CMC-LILIN LEBAH DAN GELATIN- KITOSAN-NANOKITIN
}

\author{
Asri Silvana Naiu*, Nikmawatisusanti Yusuf, Srirahayu Cahyani Yusuf \\ Yusnina S. Hudongi \\ Jurusan Teknologi Hasil Perikanan, Fakultas Perikanan dan Ilmu Kelautan, Universitas Negeri Gorontalo, \\ Kampus 1 Jalan Sudirman No. 6 Kota Gorontalo 96128 Telp (0435) 821125, Fax. (0435)821752 \\ Diterima: 4 Agustus 2021/Disetujui: 7 Desember 2021 \\ *Korespondensi: asrisilvananaiu@gmail.com
}

Cara sitasi: Naiu AS, Yusuf N, Yusuf SC, Hudongi YS. 2021. Perbedaan mutu permen jeli Kappaphycus alvarezii yang dikemas edible film berbasis gelatin-cmc-lilin lebah dan gelatin-kitosan-nanokitin. Jurnal Pengolahan Hasil Perikanan Indonesia. 24(3): 357-369.

\begin{abstract}
Abstrak
Penelitian ini bertujuan menganalisis perbedaan mutu permen jeli rumput laut yang dikemas edible film berbasis gelatin-karboksimetilselulosa (CMC)-lilin lebah dan gelatin-kitosan-nanokitin. Interaksi senyawa-senyawa berbeda dalam edible film diduga dapat memengaruhi mutu permen jeli selama penyimpanan. Perlakuan dalam penelitian ini yaitu waktu penyimpanan permen dipercepat menggunakan chamber selama 15 hari pada suhu lebih tinggi $\left(40^{\circ} \mathrm{C}\right)$ dengan kelembapan $75 \%$ yang setara dengan waktu 60 hari pada suhu ruang. Data yang diperoleh dianalisis dengan Independent T-Test (uji-t) untuk mengetahui laju transmisi uap air (WVTR) edible film, perbedaan mutu kimia dan mikrobiologi permen, serta uji-u Mann-Whitney untuk menguji perbedaan nilai hedonik selama penyimpanan. Parameter uji, yaitu WVTR dan mutu permen jeli meliputi kadar air, gula reduksi, angka lempeng total (ALT), dan nilai hedonik yang semuanya diuji pada taraf kepercayaan 95\%. Hasil uji-t menunjukkan bahwa WVTR kedua edible film gelatin berbeda tidak nyata $(p>0,05)$. Kadar air permen berbeda nyata pada hari ke-60, sedangkan gula reduksi dan TPC berbeda nyata sejak awal pengamatan. Hasil uji-u Mann-Whitney menunjukkan bahwa terdapat perbedaan nyata pada nilai kenampakan permen antar perlakuan yang dimulai dari hari ke-24, nilai aroma sejak hari ke-12, sedangkan nilai rasa dan tekstur permen berbeda tidak nyata. Mutu permen terbaik diperoleh pada perlakuan edible film gelatin kitosan-nanokitin.
\end{abstract}

Kata kunci: edible film, gelatin, nanokitin, permen jeli

\section{Quality Differences of Jelly Candy Kappaphycus alvarezii Wrapped in CMC-Beewax- Gelatin and Chitosan-Nanochitin Gelatin Based Edible Film}

\begin{abstract}
This study aimed to analyze differences in the quality of seaweed jelly candy wrapped with natural packaging of carboxymethyl cellulose (CMC)-beeswax gelatin based edible film and nanochitin-chitosan gelatin based edible film. The interaction of different compounds in edible films is thought to affect the quality of jelly candy during storage. The treatment in this study is the accelerated storage time of candy using a chamber for 15 days at a higher temperature $\left(40^{\circ} \mathrm{C}\right)$ with $75 \%$ humidity which is equivalent to 60 days at room temperature. The data obtained were analyzed by independent $\mathrm{T}$-Test to determine the differences in water vapor of transmission rate (WVTR) of edible film, the microbiological and the chemical quality of jelly candy. Mann-Whitney U-Test to assay sensory level of jelly candy wrapped with both treatments. The parameters tested were WVTR of the edible film and the quality of the jelly candy which included water content, reducing sugar content, total plate count (TPC), and sensory quality at the $95 \%$ confidence level. The T-Test showed that there were no differences in WVTR while reduction sugar and total microbial values were significantly variances from the first day and water content seemed difference at last day $\left(60^{\text {th }}\right.$ day). The
\end{abstract}


Mann-Whitney U-Test showed variances in the appearance value of the candy starting from the $24^{\text {th }}$ day, and the aroma from the $12^{\text {th }}$ day, while the taste and the texture were not significantly different. The best quality of candy was obtained from the nanochitin-chitosan gelatin based edible film.

Keyword: gelatin based edible film, jelly candy, nanochitin

\section{PENDAHULUAN}

Penganekaragaman produk pangan hasil perikanan merupakan salah satu upaya penyediaan makanan bagi masyarakat sekaligus meningkatkan daya guna komoditas perikanan. Salah satu hasil perikanan yang besar potensi pemanfaatannya adalah rumput laut. Selain dapat diekstrak menjadi karagenan, alginat, atau agar-agar yang bernilai jual tinggi, rumput laut dapat dimanfaatkan dalam bentuk segar menjadi berbagai olahan yang bergizi karena banyak mengandung mineral, vitamin, serat, dan telah diketahui secara luas bersifat antioksidan.

Salah satu bentuk diversifikasi olahan dari rumput laut yang dapat dibuat dengan mudah yaitu permen jeli. Permen ini dapat menggantikan permen-permen komersial yang terbuat dari pemanis buatan atau dengan kadar gula yang sangat tinggi sehingga dapat berakibat buruk pada kesehatan tubuh. Menurut Moniharapon (2016) permen adalah makanan olahan dari campuran gula dan sari buah atau bahan tambahan pangan yang berpenampakan jernih, transparan, serta memiliki tekstur dengan kekenyalan tertentu. Namun, seperti jenis makanan lainnya, permen jeli juga mudah mengalami perubahan mutu karena cenderung menjadi lengket akibat sifat higroskopis dari gula sehingga perlu adanya kemasan untuk melindunginya dari kontaminasi udara, uap air, dan kontaminan lainnya.

Berbagai bahan kemasan misalnya plastik dan kertas telah digunakan untuk mengemas produk ini, namun terdapat banyak kekurangan dari kemasan-kemasan tersebut, misalnya terjadi migrasi senyawa kimia monomer plastik ke dalam produk (Kim et al. 2021) dan masalah lingkungan akibat cemaran plastik. Oleh karena itu, telah mulai dikembangkan pengemas bahan organik yang memiliki sifat mirip plastik namun bersifat biodegradable, dapat langsung dimakan, misalnya pengemas makanan berbentuk edible film.
Penerapan edible film sebagai bahan kemasan potensial digunakan karena dapat melapisi produk yang berfungsi sebagai pelindung dari kerusakan secara mekanis dan aman dikonsumsi (Darni et al. 2009). Kusbiantoro (2011), Ridwan et al. (2015), Nilsuwan et al. (2016), dan Rochima et al. (2018) juga menyatakan bahwa edible film dapat digunakan sebagai kemasan karena memengaruhi kualitas makanan, keamanan pangan, mengendalikan kehilangan aroma, mempertahankan warna, mencegah terjadinya oksidasi lemak, dan memperpanjang masa simpan produk. Gennadios et al. (1994) menjelaskan bahwa edible film dihasilkan dari edible biopolimer yang dapat bersumber dari protein (gelatin, whey), polisakarida (karbohidrat dan gum), lipid serta campuran dari zat-zat aditif food grade (komposit). Nilsuwan et al. (2016) melaporkan bahwa edible film gelatin yang diinkorporasi dengan minyak kelapa sawit menunjukkan sifat penahan oksigen yang sangat baik dan memiliki sifat penghambat oksidasi lemak, namun permeabilitas air edible film yang dihasilkan masih lebih tinggi dibandingkan edible film berbahan nilon. Sifat hidrofilik dari molekul gelatin yang tinggi menyebabkannya harus dikombinasikan dengan bahan lain dalam pembuatan edible film untuk memperbaiki sifat penghalang air dari film gelatin.

Berdasarkan hasil-hasil penelitian tersebut, maka penelitian ini dilakukan dengan mengompositkan gelatin dengan bahanbahan lain seperti karboksimetil selulosa/ carboxymethil cellulose (CMC), lilin lebah, kitosan, dan nanokitin untuk memperbaiki sifat permeabilitas uap air. Nurindra et al. (2019) menemukan bahwa CMC dapat mengurangi laju transmisi uap air ke dalam edible film. Lilin lebah yang mengandung lemak digunakan sebagai sawar terhadap uap air karena bersifat hidrofobik.

Hasegawa et al. (1992) menyatakan bahwa edible film dari kitosan memiliki karakter film yang rapuh dan tidak cocok 
untuk diaplikasikan dalam kondisi kering. Ruban (2009) menjelaskan beberapa sifat yang diinginkan dari kitosan adalah film yang terbentuk tanpa penambahan bahan aditif, memiliki sifat penetrasi oksigen yang baik, permeabilitas karbon dioksida dan sifat mekanik yang baik serta aktivitas antimikroba terhadap bakteri, ragi, dan jamur, namun memiliki kelemahan, yaitu sensitivitasnya yang tinggi terhadap kelembapan. Untuk mengatasi kelemahan tersebut, maka edible film perlu diinkorporasi dengan bahan yang memiliki struktur yang lebih kuat, yaitu nanokitin. Sahraee (2017) menyatakan bahwa nanokitin dapat mengurangi kemampuan film untuk menyerap air. Naiu (2020) melaporkan bahwa edible film berbasis tapioka yang diinduksi dengan nanokitin 0,2\% dalam formula edible film memiliki laju transmisi yang rendah, yaitu $1,57 \mathrm{~g} \mathrm{H}_{2} \mathrm{O} \mathrm{m}^{-2} \mathrm{~d}^{-1}$.

Penelitian yang menguji perbedaan mutu produk permen yang dilapisi dengan edible film berbasis komposit bahan proteinselulosa-lilin lebah dan komposit bahan protein-kitosan-nanokitin belum pernah dilaporkan. Diduga terdapat perbedaan mutu permen akibat perbedaan komposisi dan reaksi antara bahan penyusun kemasan tersebut. Berdasarkan latar belakang yang dikemukakan, maka penelitian ini bertujuan untuk mengkaji perbedaan mutu permen jeli rumput laut yang dikemas dengan edible film berbasis gelatin kompleks CMC-lilin lebah dan gelatin kompleks kitosan-nanokitin selama penyimpanan.

\section{BAHAN DAN METODE Bahan dan Alat}

Bahan yang digunakan dalam penelitian ini adalah rumput laut kering ( $K$. alvarezii) yang diperoleh dari Balai Budidaya Rumput Laut, Mananggu, Kabupaten Boalemo Provinsi Gorontalo, buah naga, dan gula pasir yang dibeli di Pasar Sentral Kota Gorontalo. Gelatin tulang ikan tuna yang proses pembuatannya mengacu pada Yusuf dan Naiu (2021), lilin lebah dan gliserol (PT Dwilab Mandiri), CMC komersial (Koepoe-koepoe), kitosan (CV Biochitosan), nanokitin yang proses pembuatannya mengacu pada Naiu et al. (2020) dan akuades yang diperoleh dari Balai
Pengujian Penerapan Mutu dan Diversifikasi Produk Perikanan (BPPMDPP). Bahan untuk pengujian parameter adalah agar-agar hara, larutan Butterfield's Phosphat Buffered (BFP), agar-agar cacah lempeng/plate count agar (PCA) (Himedia M091), NaOH 96\% (Pudak Scientific), HCl 37\% (Merck), akuades (Pudak Scientific), dan etanol 95\% (Pudak Scientific).

Alat yang digunakan dalam pembuatan edible film, permen, dan alat pengujian parameter diantaranya, yaitu pengaduk magnet (Biosan MSH 300), alat penghomogen (Tokebi Platinum), timbangan digital (Ohaus EX225 DM), sentrifuga (Hettich Eba 200), termometer (Raksa, China), oven (Memmert), inkubator (Memmert).

\section{Metode}

Penelitian ini menggunakan metode eksperimental yang terdiri atas tahap penentuan formula edible film yang menggunakan gelatin, CMC, dan lilin lebah serta formula edible film yang menggunakan gelatin, kitosan, dan nanokitin. Tahap selanjutnya adalah mengaplikasikan kedua edible film tersebut pada permen jeli rumput laut dan melakukan karakterisasi mutu permen jeli selama penyimpanan. Penyimpanan dilakukan dalam climatic chamber yang dikondisikan suhunya pada $40^{\circ} \mathrm{C}$ dan $\mathrm{RH} 75 \%$ mengacu pada Afifah et al. (2017). Pembuatan permen jeli mengacu pada Ningsi et al. (2020) dengan formula yang terdiri dari buah naga merah $250 \mathrm{~g}$, gula pasir $15 \mathrm{~g}$, dan rumput laut $40 \mathrm{~g}$.

\section{Penentuan formula komplek gelatin edible film}

Tahap ini diawali dengan membuat gelatin dari tulang ikan yang mengacu pada Yusuf dan Naiu (2021), nanokitin yang mengacu pada Naiu et al. (2020), serta komplek gelatin edible film CMC dengan tambahan lilin lebah yang mengacu pada Diova et al. (2013) dengan modifikasi yang dapat dilihat pada Table 1 .

Komplek gelatin edible film kitosan nanokitin mengacu pada Yahya et al. (2015) dan Naiu (2020) dengan modifikasi yang dapat dilihat pada Table 2. 
Table 1 Composition of complex beeswaxCMC-gelatin based edible film

\begin{tabular}{lr}
\hline Ingredients (\% b/v) & Concentration (\%) \\
\hline Gelatin & 1.00 \\
Beeswax & 0.30 \\
CMC & 0.75 \\
Glycerol & 0.30 \\
\hline
\end{tabular}

Tahapan pembuatan edible film gelatinCMC-Lilin Lebah (EFG CMCLL) dapat dilihat pada Figure 1 dan edible film Gelatin-KitosanNanokitin (EFG KsNKn) pada Figure 2. Pada tahap ini, EFG CMCLL dan EFG KsNKn diuji laju transmisi uap air menggunakan metode ASTM E96 (2000).

\section{Aplikasi komplek edible film gelatin dan karakterisasi mutu permen jeli}

Tahap ini diawali dengan membuat permen jeli rumput laut yang mengikuti Ningsih et al. (2020), diikuti dengan mengaplikasikan kedua jenis edible film pada
Table 2 Composition of complex nanochitinchitosan-gelatin based edible film

\begin{tabular}{|c|c|}
\hline Ingredients & $\begin{array}{c}\text { Concentration } \\
(\%)\end{array}$ \\
\hline Gelatin $(\% \mathrm{~b} / \mathrm{v})^{*}$ & 1 \\
\hline Chitosan liquid $(\% \mathrm{v} / \mathrm{v})^{\star *}$ & 1 \\
\hline Nanochitin $(\% \mathrm{~b} / \mathrm{v})^{* * *}$ & 0,2 \\
\hline Glycerol (\% v/v) & 0,26 \\
\hline
\end{tabular}

permen jeli, penyimpanan dalam climatic chamber yang dikondisikan suhunya pada $40^{\circ} \mathrm{C}$ dan $\mathrm{RH} 75 \%$ selama dua minggu, dan melakukan karakterisasi mutu permen jeli. Pengambilan sampel setiap tiga hari sekali untuk diuji kadar air (AOAC 2005), kadar gula reduksi (SNI 2008), jumlah mikroba TPC (SNI 2006a), dan organoleptik hedonik (SNI 2006b)

\section{Analisis Data}

Perbedaan antara mutu permen yang dikemas kedua jenis edible film selama penyimpanan diuji dengan metode uji

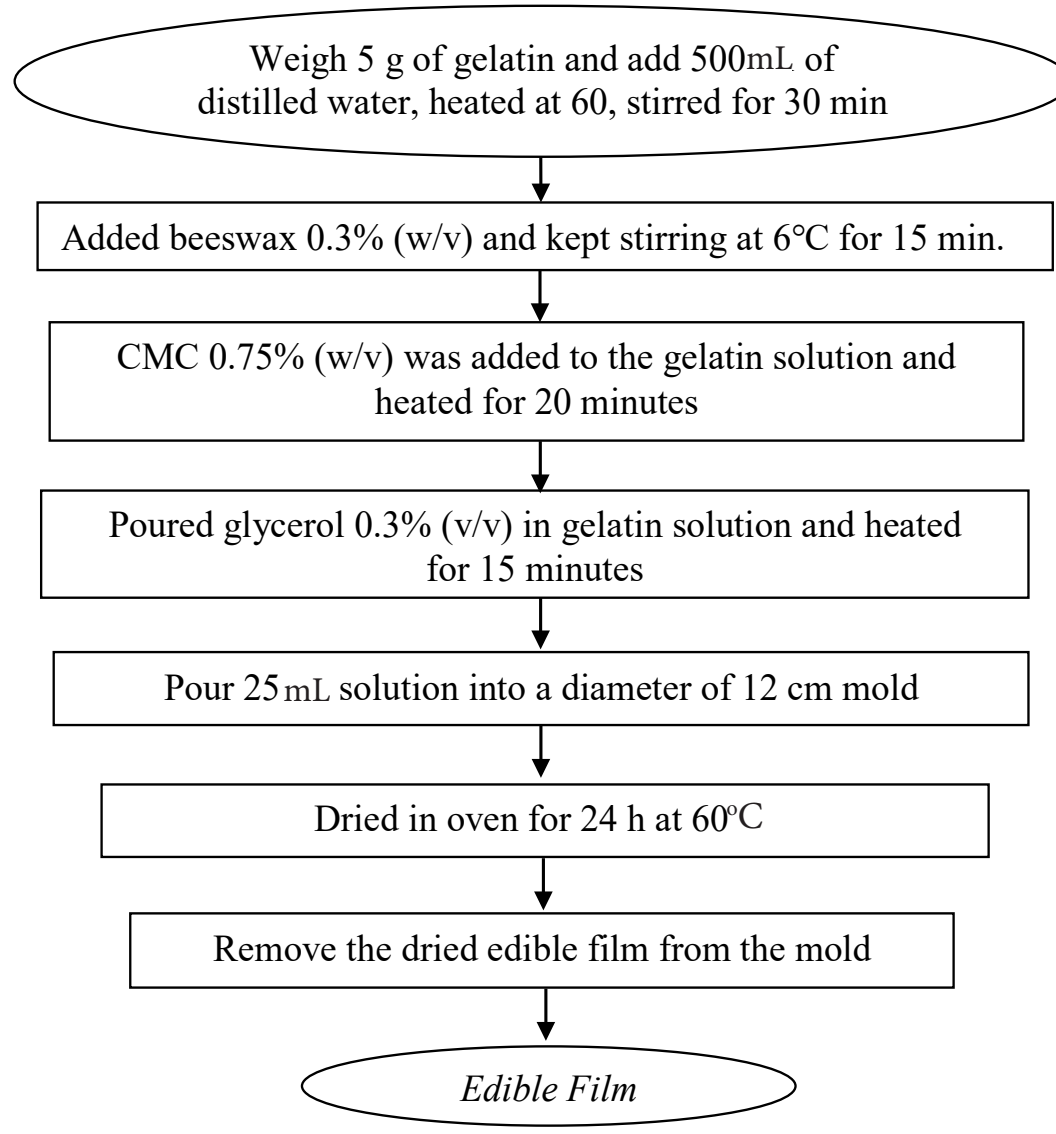

Figure 1 Flowchart of process making of complex beeswax-CMC-gelatin based edible film 


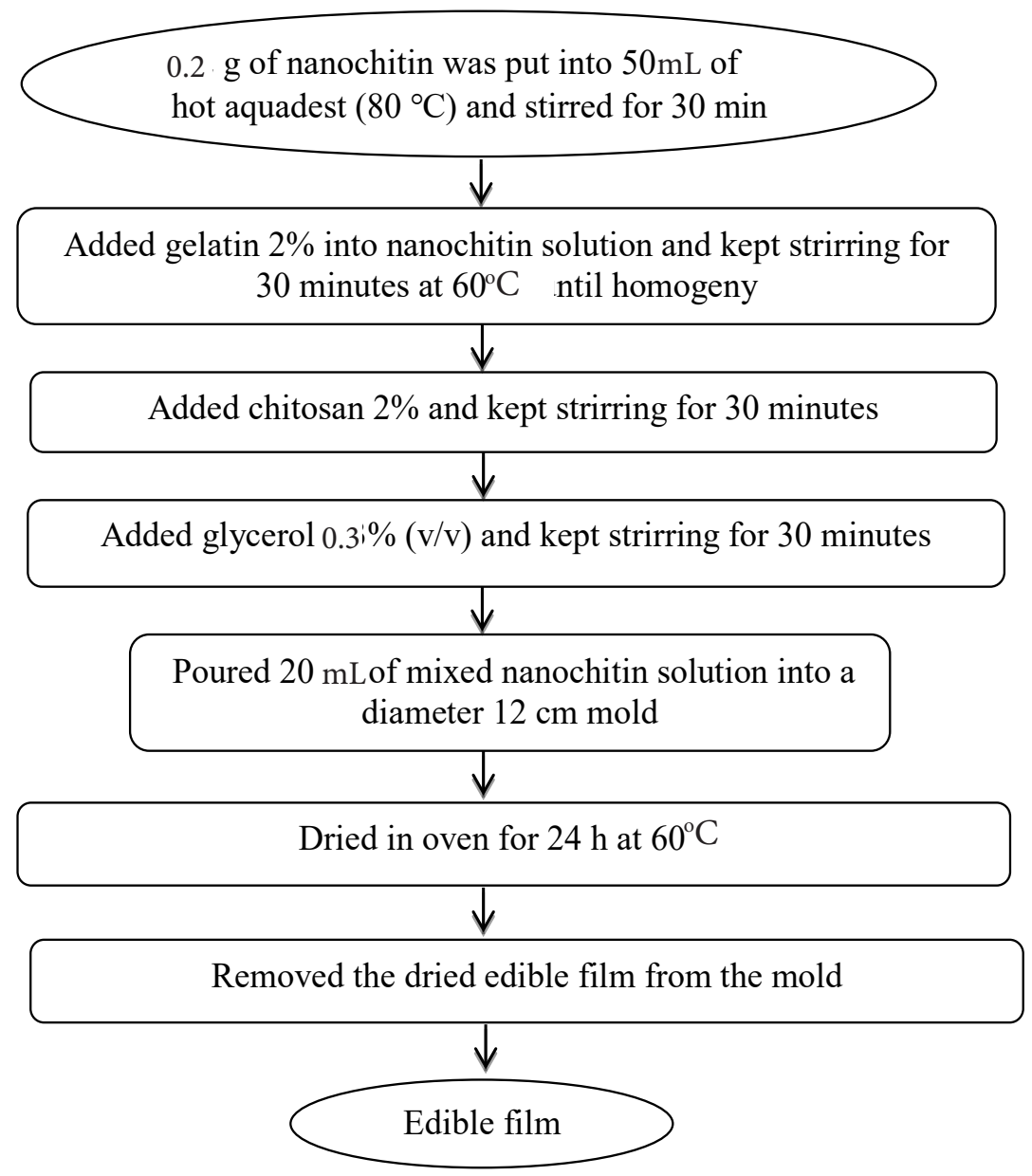

Figure 2 Flowchart of process making of complex nanochitin-chitosan-gelatin based edible film

pembedaan uji-t (Independent T-Test) untuk parameter kimia dan mikrobiologi, serta metode uji pembedaan non parametrik uji-u (Mann-Whitney U-Test) untuk parameter uji organoleptik. Semua data ditabulasi dengan bantuan aplikasi SPSS 24.

Rumus uji-t (Aminulloh 2019) sebagai berikut:

$$
\begin{aligned}
& \mathrm{t}=\frac{\overline{\mathrm{x}_{1}}-\overline{\mathrm{x}}_{2}}{s_{x 1 \times 2} \sqrt{\frac{2}{n}}} \\
& S_{x 1 \times 2}=\sqrt{\frac{1}{2}\left(S^{2} \times 1+S^{2} \times 2\right)}
\end{aligned}
$$

Keterangan:

$\mathrm{t}=$ uji t pada ukuran sampel dan varian sama $\mathrm{X}_{1}=$ nilai rata-rata sampel 1

Adapun rumus uji-u Mann-Whitney mengacu pada Sriwidadi (2011), yaitu:

$\mathrm{X} 2$ = nilai rata-rata sampel 2

$\mathrm{S}=$ standar deviasi

$\mathrm{n}=$ ulangan
$\mathrm{mL}$

$$
\begin{aligned}
& Z=\frac{U-E(U)}{\sqrt{\operatorname{Var}(\mathrm{U})}} \\
& \mathrm{U}=n_{1} n_{2}+\frac{n_{1}\left(n_{1}+1\right)}{2}-R_{1} \\
& \mathrm{E}(\mathrm{U})=n_{1} n_{2}+\frac{n_{1}\left(n_{1}+1\right)}{2}-E\left(R_{1}\right)=\frac{n_{1} n_{2}}{2} \\
& \operatorname{Var}(U)=\operatorname{var}\left(R_{1}\right)=\frac{n_{1} n_{2}\left(n_{1}+n_{2}+1\right)}{12} \\
& \text { Keterangan: } \\
& \text { R1 }=\text { total peringkat salah satu sampel. }
\end{aligned}
$$

HASIL DAN PEMBAHASAN

Laju Transmisi Uap Air Komplek Gelatin Edible Film

Hasil uji laju transmisi uap air dari komplek gelatin edible film CMC lilin lebah (EFG CMCLL) dan komplek gelatin edible film kitosan nanokitin (EFG KsNkn) 
berturut-turut sebesar $18,61 \pm 1,64 \mathrm{~g} \mathrm{H}_{2} \mathrm{O} /$ $\mathrm{m}^{2} / 24 \mathrm{jam}$ dan $23,03 \pm 3,33 \mathrm{~g} \mathrm{H}_{2} \mathrm{O} / \mathrm{m}^{2} / 24$ jam yang berdasarkan hasil uji-t berbeda tidak nyata $(p>0,05)$. Hasil yang diperoleh ini lebih tinggi dibandingkan dengan standar yang dikeluarkan oleh Japan Industrial Standard (JIS) yang hanya $10 \mathrm{~g} \mathrm{H}_{2} \mathrm{O} / \mathrm{m}^{2} / 24 \mathrm{jam}$. Laju transmisi uap air yang melebihi standar maksimum JIS ini diduga karena komposisi edible film yang didominasi oleh gelatin yang bersifat hidrofilik. Sifat hidrofilik dari suatu senyawa berpotensi untuk mengikat air/uap air dari lingkungannya. Transmisi uap air yang tinggi ini dapat terjadi karena perbedaan tekanan uap antara permukaan edible film dengan lingkungannya. Perbedaan tekanan uap semakin besar, maka akan meningkatkan laju permeabilitas oleh bagian edible film yang bersifat hidrofilik. Transmisi uap air antar lingkungan dan edible film yang semakin lama, maka semakin memperkecil jumlah uap air yang berdifusi karena kesetimbangan kimia uap air yang telah tercapai. Yam (2007) menyatakan bahwa uap air akan terabsorpsi ke dalam polimer dalam kondisi kelembapan yang tinggi dan berinteraksi dengan ikatan polar untuk menggembungkan struktur polimer sehingga pada saat yang bersamaan, permeabilitas uap juga akan meningkat dengan cepat.

Penggunaan lilin lebah $0,3 \%$ dan nanokitin $0,2 \%$ yang bersifat hidrofobik pada masing-masing perlakuan belum dapat menurunkan laju transmisi uap air karena konsentrasi yang sangat kecil dalam formula. Hasil penelitian ini sejalan dengan Togas et al. ( 2017) yang memperoleh nilai laju transmisi uap air yang cukup tinggi berkisar antara $25,34 \mathrm{~g} \mathrm{H}_{2} \mathrm{O} / \mathrm{m}^{2} / 24$ jam hingga $38,58 \mathrm{~g} \mathrm{H}_{2} \mathrm{O} / \mathrm{m}^{2} / 24$ jam pada edible film nano emulsi karagenan konsentrasi 3,5\% hingga $4,5 \%$ dengan penambahan lilin lebah $<1 \%$, namun lebih tinggi dari yang dilaporkan oleh Naiu (2020) yang dalam penelitiannya menggunakan nanokitin 0,2\% menghasilkan laju transmisi uap air yang rendah, yaitu 1,57 $\mathrm{g} \mathrm{H}_{2} \mathrm{O} / \mathrm{m}^{2} / 24$ jam. Tasha et al. (2016) yang menambahkan CMC $2 \%$ dalam formula edible film pati sorgum memperoleh laju transmisi uap air edible film yang jauh lebih tinggi, yaitu sebesar 616,226 g $\mathrm{H}_{2} \mathrm{O} / \mathrm{m}^{2} / 24$ jam. Rahardjo et al. (2014) menyatakan bahwa edible film gelatin dapat mengatur migrasi penguapan air dan merupakan sawar yang baik terhadap oksigen, karbondioksida dan lipid karena gelatin yang bersifat hidrofilik.

\section{Kadar Air}

Hasil uji perbedaan kadar air permen jeli terkemas EFG CMCLL dan EFG KsNkn selama penyimpanan dapat dilihat pada Table 3.

Berdasarkan hasil uji-t pada setiap interval pengamatan hari penyimpanan, terdapat perbedaan nyata antara kedua perlakuan yang mulai teramati pada hari ke-60 $(p<0,05)$. Kedua sampel permen jeli menunjukkan peningkatan kadar air seiring lama penyimpanan. Kadar air permen jeli terlapis EFG CMCLL berkisar antara $16,25 \% \pm 0,25$ hingga $20,75 \% \pm 0,25$ sedangkan yang terlapis EFG KsNKn berada pada kisaran 16,75\% $\pm 0,87$ hingga $21,75 \% \pm 0,25$ yang keduanya cenderung meningkat seiring lama penyimpanan. Hingga penyimpanan hari ke-48 kedua perlakuan memperlihatkan perbedaan kadar air yang tidak nyata $(p>0,05)$.

Peningkatan kadar air permen jeli selama penyimpanan dapat disebabkan karena kondisi uap air lingkungan penyimpanan yang lebih tinggi (RH 75\%) dibandingkan air dalam permen, sehingga terjadi penarikan air dari lingkungan ke dalam permen. Hal ini umum terjadi dalam sistem pangan untuk

Table 3 Difference in water content of jeli candy wrapped in EFG CMCLL and EFG KsNkn

\begin{tabular}{ccccccc}
\hline \multirow{2}{*}{ Edible film } & \multicolumn{6}{c}{ Storage day } \\
\cline { 2 - 7 } & 0 & 12 & 24 & 36 & 48 & 60 \\
\hline EFG CMCLL & $16.75 \pm 0.25^{\mathrm{a}}$ & $17.75 \pm 0.80^{\mathrm{a}}$ & $18.25 \pm 0.25^{\mathrm{a}}$ & $19.25 \pm 0.25^{\mathrm{a}}$ & $19.75 \pm 0.10^{\mathrm{a}}$ & $20.75 \pm 0.25^{\mathrm{a}}$ \\
& & & & & & \\
EFG KsNkn & $16.75 \pm 0.87^{\mathrm{a}}$ & $17.25 \pm 0.49^{\mathrm{a}}$ & $18.25 \pm 0.25^{\mathrm{a}}$ & $19.25 \pm 0.25^{\mathrm{a}}$ & $20.50 \pm 0.87^{\mathrm{a}}$ & $21.75 \pm 0.25^{\mathrm{b}}$ \\
\hline
\end{tabular}

Note: different letter on the same column show significant difference $(p<0.05)$ 
mencapai kesetimbangan kimia. Kondisi ini ditunjang juga oleh komposisi permen jeli yang terdiri dari rumput laut yang bersifat hidrokoloid dengan sifatnya yang mudah menarik air serta bersinergi dengan gula yang bersifat higroskopis. EFG CMCLL dan EFG KsNKn dengan bahan utama gelatin yang lebih bersifat hidrofilik memiliki laju transmisi uap air yang relatif tinggi, berturut-turut yaitu $18,61 \mathrm{~g} \mathrm{H}_{2} \mathrm{O} / \mathrm{m}^{2} / 24$ jam dan 23,03 $\mathrm{g} \mathrm{H}_{2} \mathrm{O} /$ $\mathrm{m}^{2} / 24$ jam sehingga sangat memungkinkan untuk melewatkan uap air dari lingkungan ke dalam permen jeli.

Pengamatan menunjukkan bahwa kadar air permen jeli yang dikemas EFG KsNKn secara nyata lebih tinggi $(p<0,05)$, diduga karena semakin lama penyimpanan semakin banyak komponen edible film yang ikut terlarut menyatu dengan permen. Hasil penelitian Naiu et al. (2020) menunjukkan bahwa kitin berpartikel nano menjadi bersifat larut dengan tingkat kelarutan sebesar 68,92\% hingga $71,72 \%$, dan dilaporkan sebelumnya oleh Rochima (2007) bahwa kitosan memiliki tingkat kelarutan 79,39\%. Hasil pengukuran laju transmisi uap air EFG KsNKn lebih tinggi dibandingkan EFG CMCLL sehingga lebih banyak menyerap air dari lingkungan. Kadar air kedua perlakuan dalam penelitian ini masih berada dalam batas penerimaan SNI permen jeli dengan nilai maksimum 20\% BSN (2008) hingga penyimpanan hari ke-48.

Kadar air hasil penelitian ini tidak berbeda dengan yang diperoleh Mahardika et al. (2014) pada permen jeli berbasis semi fine carrageenan dan alginat, yang berkisar 18-19\%, dan sejalan juga dengan Susanti (2018) yang menemukan bahwa kadar air permen jeli dalam kemasan plastik dan campurannya dengan aluminium foil meningkat seiring lama penyimpanan. Air dalam bahan pangan sangat penting karena dapat memengaruhi kenampakan, tekstur, serta citarasa makanan. Keberadaannya dalam pangan turut menentukan kesegaran dan daya tahan bahan pangan tersebut.

\section{Kadar Gula Reduksi}

Hasil uji perbedaan kadar gula reduksi permen jeli terkemas komplek gelatin edible film CMC lilin lebah (EFG CMCLL) dan komplek kitosan nanokitin (EFG KsNkn) selama penyimpanan dapat dilihat pada Table 4.

Berdasarkan hasil uji-t pada setiap interval pengamatan hari penyimpanan, terdapat perbedaan nilai rata-rata yang nyata antara kedua perlakuan sejak hari ke-0 penyimpanan $(p<0,05)$. Permen jeli terkemas EFG CMCLL secara nyata lebih tinggi kadar gula reduksinya pada akhir penyimpanan dibandingkan yang terkemas EFG KsNKn, yaitu berturut-turut $17,9 \% \pm 0,30$ dan $15,1 \% \pm 0,0$.

Kedua sampel permen jeli menunjukkan penurunan kadar gula reduksi seiring lama penyimpanan. Kadar gula reduksi permen jeli terlapis EFG CMCLL berkurang dari 22,15\% menjadi 17,9 \% sedangkan yang terlapis EFG KsNKn berkurang dari 20,5\% menjadi 15,1\% pada akhir penyimpanan. Kadar gula reduksi yang lebih rendah pada permen terkemas EFG KsNKn diduga disebabkan oleh kadar oksigen yang lebih banyak melewati edible film ini dibandingkan pada EFG CMCLL. Menurut Gennadios et al. (1994) edible film protein lebih baik dalam menghambat gas dibandingkan polisakarida, namun pada EFG KsNKn, komposisi kitosan sebagai polisakarida berada dalam jumlah yang sama dengan protein gelatin, dan nanokitin dalam jumlah yang minor sehingga mampu melewatkan oksigen ke dalam permen. Oksigen merupakan salah satu senyawa pengoksidasi yang dapat mereduksi gula. Gula reduksi adalah gula yang dapat mereduksi.

Table 4 Difference in reducing sugar content of jeli candy wrapped in EFG CMCLL and EFG KsNkn during storage

\begin{tabular}{ccccccc}
\hline \multirow{2}{*}{ Edible film } & \multicolumn{5}{c}{ Storage day } \\
\cline { 2 - 6 } & 0 & 12 & 24 & 36 & 48 & 60 \\
\hline EFG CMCLL & $22.15 \pm 0.56^{\mathrm{a}}$ & $21.15 \pm 0.30^{\mathrm{a}}$ & $20.80 \pm 0.00^{\mathrm{a}}$ & $19.85 \pm 0.35^{\mathrm{a}}$ & $19.20 \pm 0.44^{\mathrm{a}}$ & $17.90 \pm 0.30^{\mathrm{a}}$ \\
& & & & & & \\
EFG KsNkn & $20.50 \pm 0.30^{\mathrm{b}}$ & $19.50 \pm 0.00^{\mathrm{b}}$ & $17.90 \pm 0.30^{\mathrm{b}}$ & $17.60 \pm 0.00^{\mathrm{b}}$ & $14.60 \pm 1.70^{\mathrm{b}}$ & $15.10 \pm 0.00^{\mathrm{b}}$ \\
\hline
\end{tabular}

Note: different letter on the same column show significant difference $(p<0.05)$ 
Menurut Syarief dan Halid (1993), salah satu penyebab perubahan gula adalah melalui proses respirasi yang melibatkan oksigen yang dapat mengubah gula sederhana (glukosa) menjadi molekul air, gas karbondioksida, dan melepaskan panas. Hasil penelitian Panjaitan et al. (2020) mengungkap bahwa dodol yang dilapisi edible film kitosan $2 \%$ berkurang nilai aroma pada hari ke-16 karena mulai tercium aroma ketengikan. Ketengikan dapat diakibatkan oleh teroksidasinya asam-asam lemak bebas oleh oksigen. Hal ini menandakan bahwa edible film kitosan cukup permeabel terhadap oksigen. Hasil penelitian menunjukkan bahwa kedua sampel permen jeli yang dikemas masing-masing dengan EFG KsNKn dan EFG CMCLL dapat mempertahankan keberadaan gula reduksi hingga akhir penyimpanan karena kedua perlakuan masih berada pada batas kadar gula menurut BSN (2008) yaitu maksimal 25\%.

\section{Jumlah Total Mikroba}

Hasil uji perbedaan jumlah mikroba permen jeli terkemas EFG CMCLL dan EFG KsNkn selama penyimpanan dapat dilihat pada Table 5.

Berdasarkan hasil uji-t pada setiap interval pengamatan hari penyimpanan, terdapat perbedaan nilai rata-rata yang nyata antara kedua perlakuan sejak hari ke-0 penyimpanan $(\mathrm{p}<0,05)$. Permen jeli terkemas EFG CMCLL secara nyata lebih tinggi jumlah mikrobanya dibandingkan yang terkemas EFG KsNKn. Kedua sampel permen jeli menunjukkan peningkatan jumlah mikroba seiring lama penyimpanan, namun hingga akhir pengamatan hari ke-60 total mikroba sampel EFG CMCLL sebesar 3,61 $\pm 0,01 \mathrm{cfu} / \mathrm{g}$

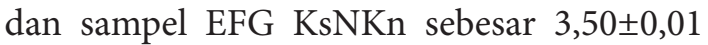
$\mathrm{cfu} / \mathrm{g}$, masih berada dalam batas maksimal yang disyaratkan BSN (2008) yaitu 4,70 cfu/g.

Jumlah mikroba yang lebih rendah pada permen terkemas EFG KsNKn diduga disebabkan oleh adanya sifat antimikroba yang dimiliki oleh kitosan dan nanokitin yang terdapat dalam edible film. Wahyuni dan Khaeruni (2014) menjelaskan bahwa mekanisme penghambatan oleh kitosan berasal dari struktur polimernya yang mempunyai gugus amin bermuatan positif yang dapat berinteraksi dengan muatan negatif suatu molekul, misalnya protein dari mikroba sehingga menghambat pertumbuhan mikroba. Kumar et al. (2004) menyatakan bahwa struktur khusus dengan kelompok amino reaktif yang dimiliki kitosan menyebabkannya menjadi senyawa bioaktif yang menunjukkan sifat antimikroba. Yahya et al. (2015) yang mengaplikasikan edible coating kitosan $2 \%$ pada dodol ketan dapat memperpanjang masa simpan dodol hingga lebih dari 10 hari dibandingkan perlakuan tanpa kitosan yang hanya bertahan hingga dua hari. Menurut Zheng et al. (2003) mekanisme penghambatan pertumbuhan mikroorganisme oleh kitosan yaitu dengan cara membentuk membran polimer pada permukaan sel sehingga menghambat nutrisi masuk ke dalam sel, sedangkan penghambatan kitosan berpartikel nano pada E. coli diduga melalui mekanisme masuknya zat ke dalam sel sehingga mengganggu metabolisme bakteri.

Penambahan kitin dalam bentuk partikel nano yang memiliki kelarutan yang cukup tinggi menyebabkan nanokitin yang larut dalam edible film dapat mengantarkan senyawa antimikroba yang dimilikinya ke dalam permen sehingga dapat memperlambat pertumbuhan mikroorganisme. Naiu et al. (2020) menemukan bahwa tingkat kelarutan kitin berpartikel nano berkisar antara 68,92\% hingga $71,72 \%$, dan seperti yang dinyatakan oleh Krochta et al. (1994) bahwa edible film adalah lapisan tipis yang berfungsi sebagai penahan perpindahan massa (antara lain kelembapan, oksigen, lipid, zat terlarut) dan atau sebagai pembawa bahan makanan dan

Table 5 Difference in TPC of jeli candy wrapped in EFG CMCLL and EFG KsNkn during storage

\begin{tabular}{ccccccc}
\hline \multirow{2}{*}{ Edible film } & \multicolumn{6}{c}{ Storage day } \\
\cline { 2 - 6 } & 0 & 12 & 24 & 36 & 48 & 60 \\
\hline EFG CMCLL & $1.84 \pm 0.06^{\mathrm{a}}$ & $2.46 \pm 0.03^{\mathrm{a}}$ & $2.78 \pm 0.08^{\mathrm{a}}$ & $3.13 \pm 0.00^{\mathrm{a}}$ & $3.45 \pm 0.00^{\mathrm{a}}$ & $3.61 \pm 0.00^{\mathrm{a}}$ \\
EFG KsNkn & $1.39 \pm 0.09^{\mathrm{b}}$ & $2.14 \pm 0.10^{\mathrm{b}}$ & $2.52 \pm 0.03^{\mathrm{b}}$ & $2.88 \pm 0.06^{\mathrm{b}}$ & $3.24 \pm 0.00^{\mathrm{b}}$ & $3.50 \pm 0.00^{\mathrm{b}}$ \\
\hline Note: different letter on the same column show significant difference $(p<0.05)$ &
\end{tabular}


bahan tambahan makanan (antimikroba, antioksidan, dan flavor) untuk meningkatkan kualitas.

EFG CMCLL yang diperkaya dengan lilin lebah masih dapat menghambat pertumbuhan mikroba hingga akhir pengamatan diduga karena sifat lilin lebah yang hidrofobik serta sifat CMC yang sebagian hidrofobik, namun interaksi ketiga bahan tersebut masih dapat menghalangi penambahan uap air ke dalam produk. Keberadaan air bebas dalam produk dapat menjadi media bagi pertumbuhan mikroba. Kanani et al. (2018) melaporkan bahwa penambahan lilin lebah dalam edible film dapat mengurangi susut berat buah karena lilin lebah dapat menahan laju respirasi buah sehingga kelembapan yang memengaruhi berat buah tetap terjaga.

\section{Mutu Organoleptik Kenampakan}

Hasil uji perbedaan mutu organoleptik permen jeli terkemas EFG CMCLL dan EFG KsNkn selama penyimpanan dapat dilihat pada Table 6.

Berdasarkan hasil uji-u Mann-Whitney, maka perbedaan nilai kenampakan mulai terlihat sejak hari ke-24 penyimpanan $(p<0,05)$ yang nilai rata-ratanya diungguli oleh permen terkemas EFG KsNKn. Kenampakan permen jeli terlapis EFG KsNKn berada pada kriteria suka hingga netral sedangkan yang terlapis EFG CMCLL memperoleh kesan suka hingga agak tidak suka oleh panelis seiring lama penyimpanan. Diduga bahwa kitosan dan nanokitin dalam formula EFG KsNKn memiliki senyawa-senyawa yang bersifat antimikroba dan antijamur sehingga memberikan kenampakan yang masih dianggap netral oleh panelis hingga hari ke-60 penyimpanan. Berbeda halnya dengan permen terlapis EFG CMCLL yang telah berada di bawah kesan netral sejak hari ke-48. Jamur pada produk memberikan kenampakan kusam dan kotor sehingga dapat memengaruhi penilaian panelis. Panjaitan et al. (2020) yang melapisi dodol dengan edible film dari kitosan menghasilkan dodol yang tidak berubah warnanya hingga hari ke-12 dan berbeda nyata dengan dodol tanpa lapisan kitosan yang hanya dapat mempertahankan warna dodol kurang dari 4 hari penyimpanan.

Kenampakan permen jeli selain dilihat dariwarnanya, bentukserta tekstur permukaan juga diamati oleh panelis. Permen terlapis EFG CMCLL tampak lebih kusam setelah hari ke-36. Hal ini mungkin juga disebabkan oleh keberadaan gelatin sebagai penyusun utama dalam EFG CMCLL yang bersifat hidrofilik menyebabkan laju transmisi uap air edible film yang tinggi sehingga air dalam permen bertransmisi ke luar produk lebih banyak dan mengakibatkan produk menjadi kisut dan tekstur permukaan tampak kasar. Bahan antimikroba dan antijamur yang tidak terdapat dalam formula dapat menyebabkan warna kusam pada permukaan permen.

Table 6 Organoleptic of jeli candy wrapped in EFG CMCLL and EFG KsNkn during storage

\begin{tabular}{ccccccccc}
\hline \multirow{2}{*}{ Day } & \multicolumn{2}{c}{ Appearance } & \multicolumn{2}{c}{ Flavour } & \multicolumn{2}{c}{ Aroma } & Texture \\
\cline { 2 - 8 } & EFG CMCLL & EFG KsNkn & EFG CMCLL & EFG KsNkn & EFG CMCLL & EFG KsNkn & EFG CMCLL & EFG KsNkn \\
\cline { 2 - 8 } 0 & $6.60 \pm 0.80^{\mathrm{a}}$ & $6.70 \pm 1.40^{\mathrm{a}}$ & $6.50 \pm 1.00^{\mathrm{a}}$ & $6.20 \pm 1.40^{\mathrm{a}}$ & $6.00 \pm 1.30^{\mathrm{a}}$ & $6.50 \pm 1.20^{\mathrm{a}}$ & $6.90 \pm 1.40^{\mathrm{a}}$ & $7.00 \pm 1.00^{\mathrm{a}}$ \\
12 & $6.33 \pm 0.87^{\mathrm{a}}$ & $6.36 \pm 1.25^{\mathrm{a}}$ & $6.04 \pm 1.20^{\mathrm{a}}$ & $6.24 \pm 1.05^{\mathrm{a}}$ & $5.80 \pm 1.10^{\mathrm{a}}$ & $6.27 \pm 1.20^{\mathrm{b}}$ & $6.40 \pm 1.40^{\mathrm{a}}$ & $6.80 \pm 1.10^{\mathrm{a}}$ \\
24 & $5.75 \pm 0.99^{\mathrm{a}}$ & $6.44 \pm 1.04^{\mathrm{b}}$ & $5.88 \pm 1.08^{\mathrm{a}}$ & $6.40 \pm 0.96^{\mathrm{a}}$ & $5.00 \pm 1.20^{\mathrm{a}}$ & $6.50 \pm 1.10^{\mathrm{b}}$ & $5.50 \pm 1.56^{\mathrm{a}}$ & $5.24 \pm 1.56^{\mathrm{a}}$ \\
36 & $4.83 \pm 0.87^{\mathrm{a}}$ & $5.76 \pm 0.88^{\mathrm{b}}$ & $5.50 \pm 0.90^{\mathrm{a}}$ & $5.80 \pm 1.00^{\mathrm{a}}$ & $4.60 \pm 0.80^{\mathrm{a}}$ & $5.80 \pm 0.80^{\mathrm{b}}$ & $5.50 \pm 1.29^{\mathrm{a}}$ & $5.60 \pm 1.32^{\mathrm{a}}$ \\
48 & $4.20 \pm 1.18^{\mathrm{a}}$ & $5.28 \pm 1.31^{\mathrm{b}}$ & $4.92 \pm 1.25^{\mathrm{a}}$ & $5.28 \pm 1.43^{\mathrm{a}}$ & $4.20 \pm 0.80^{\mathrm{a}}$ & $5.00 \pm 1.30^{\mathrm{b}}$ & $4.88 \pm 1.39^{\mathrm{a}}$ & $5.40 \pm 1.35^{\mathrm{a}}$ \\
60 & $3.70 \pm 1.20^{\mathrm{a}}$ & $4.80 \pm 1.20^{\mathrm{b}}$ & $4.50 \pm 1.20^{\mathrm{a}}$ & $4.80 \pm 1.30^{\mathrm{a}}$ & $4.20 \pm 1.10^{\mathrm{a}}$ & $4.50 \pm 1.20^{\mathrm{b}}$ & $4.42 \pm 1.28^{\mathrm{a}}$ & $4.84 \pm 1.25^{\mathrm{a}}$
\end{tabular}

Note: different letter on the same row in the same parameter show significant difference $(p<0.05)$ 


\section{Rasa}

Hasil uji perbedaan nilai rasa permen jeli terkemas EFG CMCLL dan kompleks kitosan nanokitin EFG KsNkn selama penyimpanan dapat dilihat pada Table 6.

Hasil uji-u Mann-Whitney pada setiap interval pengamatan hari penyimpanan, terdapat perbedaan yang tidak nyata antara kedua perlakuan $(p>0,05)$. Nilai rasa permen jeli pada kedua perlakuan berada pada kriteria suka hingga netral oleh panelis dan cenderung menurun seiring lama penyimpanan.

Penurunan nilai rasa permen kedua perlakuan kemasan diduga disebabkan oleh meningkatnya kadar air seiring lama penyimpanan. Air yang berlebihan dalam formula dapat memudarkan rasa asam dan manis dari permen. Perbedaan rasa yang tidak nyata pada kedua perlakuan kemasan mungkin diakibatkan oleh rasa buah naga yang mendominasi formula permen jeli. Buah naga dengan rasa asam manis yang kuat tidak bisa ditutupi oleh edible film gelatin kompleks yang tidak memiliki rasa. Keberadaan gelatin sebagai bahan utama pada kedua edible film berpotensi menarik air dari lingkungan yang lebih tinggi kelembapannya dan masuk ke dalam produk. CMC yang bersifat semihidrofobik dan lilin lebah yang hidrofobik dalam EFG CMCLL serta kitosan dan nanokitin yang bersifat semihidrofobik dalam EFG KsNKn dalam konsentrasi yang kecil belum dapat menghambat masuknya uap air ke dalam permen. Peningkatan kadar air selama penyimpanan yang dipengaruhi oleh proses oksidasi glukosa (gula reduksi) menjadi karbondioksida dan air mengakibatkan rasa permen semakin hambar akibat bertambahnya air. Islamiyah (2013) menyatakan bahwa semakin lama penyimpanan, glukosa mengalami oksidasi membentuk air dan karbondioksida. Moniharapon (2016) yang menggunakan dua jenis kemasan aluminium foil dan polietilena pada permen jeli rumput laut juga mendapatkan nilai rasa yang tidak begitu berbeda seiring lama penyimpanan.

\section{Aroma}

Hasil uji perbedaan nilai aroma permen jeli terkemas edible film EFG CMCLL dan EFG KsNkn selama penyimpanan dapat dilihat pada Table 6.
Berdasarkan hasil uji-u Mann-Whitney pada setiap interval pengamatan hari penyimpanan, terdapat perbedaan nyata $(p<0,05)$ pada aroma permen jeli antara dua perlakuan kemasan yang terdeteksi sejak hari ke-12 penyimpanan. Permen jeli terkemas EFG KsNKn secara nyata lebih disukai nilai aromanya dibandingkan yang terkemas EFG CMCLL. Aroma permen jeli terlapis EFG KsNKn berada pada kriteria suka hingga agak tidak suka sedangkan yang terlapis EFG CMCLL mendapatkan kesan yang sedikit lebih rendah, yaitu agak suka hingga agak tidak suka oleh panelis seiring lama penyimpanan. Penilaian panelis terhadap kedua perlakuan semakin menurun seiring lama penyimpanan.

Perubahan menurun nilai aroma selama penyimpanan diduga disebabkan oleh penguraian senyawa-senyawa volatil baik yang terkandung dalam permen maupun edible film. Permen yang terkemas edible film gelatin mengalami oksidasi dan hidrolisis selama penyimpanan karena selain bersifat transparan yang dapat melewatkan cahaya, gelatin yang digunakan juga mengandung lemak cukup tinggi yang memicu terjadinya oksidasi. Penurunan kadar gula dan peningkatan kadar air permen memengaruhi senyawa lain untuk bereaksi menghasilkan senyawa volatil.

Setyaningsih et al. (2010) menyatakan bahwa aroma dihasilkan dari interaksi zat-zat dengan jutaan rambut getar pada sel epitelium olfaktori yang terletak di langit-langit rongga hidung. Aroma atau bau yang dihasilkan berasal dari zat yang bersifat menguap (volatil) dan sedikit larut dalam air atau dalam minyak. Menurut Ketaren (2005), cahaya adalah akselerator terhadap timbulnya ketengikan, kombinasi dari oksigen dan cahaya dapat mempercepat proses oksidasi.

Perbedaan nilai aroma yang nyata pada kedua sampel permen disebabkan karena jenis edible film yang berbeda. Data hasil penelitian menunjukkan bahwa EFG KsNKn lebih lama mempertahankan aroma permen dibandingkan EFG CMCLL. Hal ini diduga karena jumlah bakteri yang lebih banyak pada permen terlapis EFG CMCLL turut meningkatkan jumlah enzim pengurai lemak dalam permen sehingga lemak terhidrolisis 
menjadi gliserol dan asam-asam lemak dan menjadi mudah teroksidasi menyebabkan bau tengik yang menurunkan penilaian panelis. Syarief dan Halid (1993) menjelaskan bahwa adanya air bebas dalam bahan pangan dapat menyebabkan terjadinya hidrolisis lemak yang distimulasi oleh adanya asam dan enzim penghidrolisis lemak. Enzim dapat berasal dari jaringan tanaman, hewan, maupun mikroba.

\section{Tekstur}

Hasil uji perubahan hedonik tekstur permen jeli dan perbedaan nilai tekstur permen jeli terkemas edible film EFG CMCLL dan EFG KsNkn selama penyimpanan dapat dilihat pada Table 6 .

Berdasarkan hasil uji-u Mann-Whitney pada setiap interval pengamatan hari penyimpanan, terdapat perbedaan yang tidak nyata antara kedua perlakuan $(p>0,05)$. Kedua sampel permen jeli menunjukkan penurunan nilai tekstur seiring lama penyimpanan. Tekstur permen jeli terlapis EFG KsNKn berada pada kriteria suka hingga netral sedangkan yang terlapis EFG CMCLL memperoleh kesan suka hingga agak tidak suka oleh panelis seiring lama penyimpanan. Tekstur permen jeli di awal pengamatan adalah kenyal saat digigit sehingga disukai panelis, namun seiring lama penyimpanan, kekenyalannya berubah menjadi mengeras baik pada permen yang dilapisi EFG KsNKn maupun pada kemasan EFG CMCLL, sehingga penilaian panelis menjadi berkurang.

Pengerasan permen terjadi karena peningkatan kadar air permen selama penyimpanan yang secara nyata tidak berbeda pada kedua perlakuan edible film. Rumput laut yang merupakan salah satu bahan penyusun permen dan gelatin dalam edible film terdapat dalam komposisi yang sama pada kedua perlakuan dan merupakan bahan-bahan hidrokoloid yang bersifat mengikat air. Air yang terperangkap di dalam akan membentuk struktur yang kuat karena berikatan dengan CMC pada EFG CMCLL, serta kitosan dan nanokitin pada EFG KsNKn. Berdasarkan hasil pengujian kadar air (Table 3), terjadi peningkatan kadar air seiring lama penyimpanan. Kondisi ini menyebabkan semakin banyak air yang terperangkap dalam produk diduga karena keberadaan dan sifat komponen-komponen penyusun edible film pada kedua perlakuan. Hal ini diperkuat juga dengan hasil uji laju transmisi uap air pada kedua edible film yang berbeda tidak nyata pada kisaran 18,61 hingga $23,03 \mathrm{~g} \mathrm{H}_{2} \mathrm{O} / \mathrm{m}^{2} / 24 \mathrm{jam}$. Keberadaan rumput laut sebagai salah satu komponen permen bersinergi memperkuat struktur produk selama penyimpanan sehingga menjadi lebih keras. Hal ini sesuai dengan yang dinyatakan oleh Salamah et al. (2006) dan Harijono et al. (2001) bahwa komponen karagenan pada konsentrasi berlebih menghasilkan tekstur permen jeli yang keras. Karagenan merupakan bahan yang tergolong dalam fikokoloid hasil ekstraksi dari rumput laut.

Perbedaan yang tidak nyata $(p>0,05)$ pada kedua permen hasil perlakuan selama penyimpanan diduga juga karena edible film kedua perlakuan didominasi oleh gelatin dalam jumlah yang sama. Hasil uji kadar air yang merupakan salah satu faktor yang berpengaruh terhadap tekstur menunjukkan kecenderungan peningkatan jumlah yang sama dan perbedaan nyata yang hanya terlihat di akhir penyimpanan.

\section{KESIMPULAN}

Hasil penelitian menunjukkan bahwa kadar air permen terlapis EFG CMCLL dan EFG KsNKn terlihat berbeda nyata hanya pada hari terakhir pengamatan dan kedua perlakuan melebihi batas SNI yaitu di atas $20 \%$ pada hari tersebut. Perbedaan nyata pada kadar gula reduksi dan jumlah mikroba (TPC) permen dimulai sejak hari ke-0, kenampakan berbeda nyata dimulai dari hari ke-24, dan nilai aroma sejak hari ke-12. Nilai rasa dan tekstur dari kedua perlakuan menunjukkan perbedaan yang tidak nyata pada setiap pengamatan selama penyimpanan. Permen yang dilapisi EFG KsNKn secara nyata lebih baik dibandingkan EFG CMCLL.

\section{DAFTAR PUSTAKA}

Afifah K, Sumaryati E, Sui M. (2017). Studi pembuatan permen jelly dengan variasi konsentrasi sari kulit buah naga (Hylocereus costaricencis) dan ekstrak 
angkak. Agrika Ilmu-Ilmu Pertanian. 11(2): 206-220.

Aminulloh M. (2019). Uji beda dua ratarata variabel independen menggunakan metode bootstrap dan aplikasinya di R. [Skripsi]. Malang(ID): Universitas Islam Negeri Maulana Malik Ibrahim].

[ASTM]. American Society for Testing and Materials. (2000). Standard test methods for water vapor transmission of materials. (Patent No. E96).

[BSN]. Badan Standardisasi Nasional. (2008). Standar Nasional Indonesia 3547.2 Kembang Gula Bagian 2: Lunak.

Darni Y, Utami H, Asriasi. (2009). Peningkatan hidrofobisitas dan sifat fisik plastik biodegradabel pati tapioka dengan penambahan selulosa residu rumput laut Eucheuma spinossum. Lampung (ID): Fakultas Teknik Unila.

Diova DA, Darmanto YS, Rianingsih L. (2013). Karakteristik edible film komposit semirefined karaginan dari rumput laut Eucheuma cottonii dan beeswax. Jurnal Pengolahan Dan Bioteknologi Hasil Perikanan. 2(4): 1-10.

Gennadios A, Weller CL, Gooding CH. (1994). Measurement errors in water vapor permeability of highly permeable, hydrophilic edible films. Journal of Food Engineering. 21(4): 395-409.

Harijono Kusnadi J, Mustikasari S. (2001). Pengaruh kadar karaginan dan total padatan terlarut sari buah apel muda terhadap aspek kualitas permen jelly. Jurnal Teknologi Pertanian. 2(2): 110-116.

Hasegawa M, Isogai A, Onabe F, Usuda M. (1992). Characterization of cellulosechitosan blend films. Journal of Applied Polymer Science. 45: 1873-1879.

Kanani N, Ekasari, Wardalia, Subkhan A, Rizky R. (2018). Pengaruh penambahan gliserol dan lilin lebah pada susut berat buah sawo khas Banten. Jurnal Konversi Universitas Muhammadiyah Jakarta. 7(2): 37-44.

Ketaren S. (2005). Minyak dan lemak pangan. Jakarta(ID): Universitas Indonesia.

Kim HS, Lee YJ, Koo YJ, Pack EC, Lim KM, Choi DW. (2021). Migration of monomers, plastic additives, and non- intentionally added substances from food utensils made of melamine-formaldehyde resin following ultraviolet sterilization. Food Control. 125 (February): 107981.

Krochta J, Baldwin E, Nisperos-Carriedo M. (1994). Edible coating and films to improve food quality. Lancaster(US): Technomic Publication.

Kumar R, Muzzarelli RAA, Muzzarelli C, Sashiwa H, Domb A. (2004). Chitosan chemistry and pharmaceutical perspectives. Journal of Chemistry. Review. 104 (12): 6017-6084.

Kusbiantoro B. (2011). Kajian perubahan flavor buah durian terolah minimal berpelapis edibel selama penyimpanan. [Disertasi]. Bogor(ID): Institut Pertanian Bogor.

Mahardika BC, Darmanto YS, Dewi EN. (2014). Karakteristik permen jelly dengan penggunaan campuran semi refined carrageenan dan alginat dengan konsentrasi berbeda. Jurnal Pengolahan Dan Bioteknologi Hasil Perikanan. 3(4): 112-120.

Moniharapon A. (2016). Karakteristik kimia dan organoleptik permen jelly rumput laut the chemical and organoleptic properties of seaweed jelly. Jurnal Penelitian Teknologi Industri. 8(2): 91-96.

Naiu AS. (2020). Edible film berbasis nanokitin dan nanokaragenan serta aplikasinya pada udang rebus tanpa kulit. [Disertasi]. Manado (ID): Universitas Sam Ratulangi.

Naiu AS, Berhimpon S, Montolalu IR, Kawung NJ, Suptijah P. (2020). The effect of hclthermal pressure hydrolysis and highspeed destruction of chitin on particle size distribution and functional group of nano-chitin compound. Current Research in Nutrition and Food Science. 8(1): 197205.

Nilwan K, Benjakul S, Prodpran T. (2016). Quality changes of shrimp cracker covered with fish gelatin film without and with palm oil incorporated during storage. International Aquatic Research. 8(3): 227-238.

Ningsi M, Naiu AS, Yusuf N. (2020). Karakteristik mutu permen buah naga merah (Hylocereus polyrhizus) yang 
difortifikasi rumput laut (Kappaphycus alvarezii). Jambura Fish Processing Journal. 2(1): 12-20.

Nurindra AP, Alamsjah AM, Sudarno S. (2019). Karakterisasi edible film dari pati propagul mangrove lindur (Bruguiera gymnorrhiza) dengan penambahan Carboxymethyl Cellulose (CMC) sebagai pemlastis. Jurnal Ilmiah Perikanan Dan Kelautan. 7(2): 125-132.

Panjaitan P, Fiani R, Aripudin, AdiC, Soeprijadi L. (2020). Pengaruh penambahan edible coating kitosan rajungan (Portunus pelagicus) terhadap sensori dodol betawi. Jurnal Airaha. 9(2): 155-160.

Rochima E. (2007). Karakterisasi kitin dan kitosan asal limbah rajungan Cirebon Jawa Barat. Buletin Teknologi Hasil Perikanan. X(1): 9-22.

Rochima E, Fiyanih E, Afrianto E, Joni IM, Subhan U, Panatarani C. (2018). Efek Penambahan suspensi nanokitosan pada edible coating terhadap aktivitas antibakteri. Jurnal Pengolahan Hasil Perikanan Indonesia. 21(1): 127.

Ruban S. (2009). Biobased packagingaplication in meat industry. Journal of Food Technology. 2(2): 79-82.

Sahraee S. (2017). Effect of corn oil on physical, thermal, and antifungal properties of gelatin-based nanocomposite films containing nano chitin. LWT-Food Science and Technology.

Salamah E, Erungan AC, Retnowati Y. (2006). Pemanfaatan Gracilaria sp. dalam pembuatan permen jelly. Jurnal Pengolahan Hasil Perikanan Indonesia. 9(1): 39-48.

Setyaningsih D, Apriyantono A, Sari M. (2010). Analisis Sensoris: Untuk industri pangan dan agro (Raharjo S, Adawiyah (Ed.)). Bogor: IPB Press.

Sriwidadi T. (2011). Penggunaan uji MannWhitney pada analisis pengaruh pelatihan wiraniaga dalam penjualan produk baru. Binus Business Review. 2(2): 751-762.

Susanti R. (2018). Pengaruh kemasan berbeda terhadap mutu permen jelly rumput laut (Gracilaria sp.) selama penyimpanan suhu ruang [Skripsi]. Universitas Riau.
Syarief R, Halid H. (1993). Teknologi penyimpanan pangan. Kerjasama dengan Pusat Antar Universitas Pangan dan Gizi IPB. Jakarta: Arcan.

Tasha N, Garnida Y, Cahyadi W. (2016). Pemanfaatan pati sorgum (Sorghum bicolor) dengan bahan penstabil CMC terhadap karakteristik edible packaging bumbu mie instan. Bandung (ID): Universitas Pasundan Bandung.

Togas C, Berhimpon S, Montolalu RI, Dien AH, Mentang F. (2017). Karakteristik fisik edible film komposit karaginan dan lilin lebah menggunakan proses nanoemulsi. Jurnal Pengolahan Hasil Perikanan Indonesia. 20(3): 468-477.

Wahyuni S, Khaeruni A. (2014). Kitosan cangkang udang windu sebagai pengawet fillet ikan gabus (Channa striata). Jurnal Pengolahan Hasil Perikanan Indonesia. 16(3): 233-241.

Warkoyo, Rahardjo B, Marseno WD, Karyadi NWJ. (2014). Sifat fisik, mekanik dan barrier edible film berbasis pati umbi kimpul (Xanthosoma sagittifolium) yang diinkorporasi dengan kalium sorbat. Agritech. 34(1): 72-81.

Yahya K, Naiu AS, Yusuf N. (2015). Karakteristik organoleptik dodol ketan yang dikemas dengan edible coating dari kitosan rajungan selama penyimpanan suhu ruang. Nike Jurnal Ilmiah Perikanan Dan Kelautan. 3(3): 111-117.

Yam K. (2007). Gas permeation of packaging materials. Di dalam Yam K, Editor. The Wiley Encyclopedia of Packaging Technology (pp. 551-555). US: John Wiley $\&$ Sons Inc.

Yusuf N, Naiu AS. (2021). Ekstraksi gelatin tulang ikan tuna Thunnus sp. menggunakan cuka aren. Patent No. S00202101217. Jakarta (ID): Direktorat Jenderal Kekayaan Intelektual.

Zhong QP, Xia WS. (2008). Physicochemical properties of edible and preservative films from chitosan/cassava starch/gelatin blend plasticized with glycerol. Food Technology and Biotechnology. 46(3): 262-269. 